\title{
Fä, turs och stunget kön: Några tankar om så kallade runnamn och benämningar på runor
}

\section{Patrik Larsson}

\section{Inledning}

Per Stilles intressanta och uppslagsrika avhandling Runstenar och runristare i det vikingatida Fjädrundaland. En studie i attribuering är ett pionjärarbete vad gäller attribuering av runstenar. ${ }^{1}$ Det som främst sticker ut är det metodiska greppet, att mer eller mindre förutsättningslöst försöka gruppera runstenar utan hänsyn till de så kallade ristarsignaturerna (eller utförarformlerna i Stilles terminologi). I avhandlingen återfinns också några andra företeelser som till viss del avviker från gängse runologisk praxis, framför allt hur runtexter återges, vilka namnformer runristare får på modern svenska och hur runorna omnämns. Jag kommer här att endast mycket kort beröra de två förstnämnda företeelserna för att sedan ägna lite mer utrymme åt den tredje.

Då runtexter ska återges i skrift används vanligen translitterering med fetstilta gemener, dvs. runorna ges en motsvarande latinsk bokstav enligt en någorlunda etablerad princip (viss variation förekommer dock). I vilken grad den motsvarande latinska bokstaven ger en riktig uppfattning om runans ljudvärde varierar, och i vissa fall kan den nog leda tanken fel, åtminstone för ovana läsare av runologisk litteratur. Stille förespråkar därför att texterna ska återges med runtecken, ${ }^{2}$ vilket dock inte fått någon större efterföljd. Han använder också moderna former på runristarnas namn; ${ }^{3}$ en del av dessa, som Balle, Fot och Livsten, är fullt etablerade och har använts sedan länge, medan andra, som Lille, Tidkomme och Öpe, är betydligt mer ovanliga, ${ }^{4}$ även om den sistnämnda förekommer en del numera. Den tredje aspekten handlar om hur runorna benämns; enligt Stille har de namn, vilka han dessutom konsekvent återger i nusvensk tappning. ${ }^{5}$ Just denna tredje aspekt tänkte jag som sagt ta upp i lite mer detalj i de följande avsnitten.

\section{Något om så kallade runnamn}

Som framgått av avsnitt 1 vill Stille benämna runorna med vad han kallar deras namn. Detta är på intet sätt någon ny idé, utan sådana finns belagda i manuskript från kontinenten och Storbritannien från 800-talet och framåt och på svensk botten går traditionen åtminstone tillbaka till 1500-talet (Olaus Petri, Johan Bure), med en vidareutveckling

1 Stille 1999.

2 Stille $1999 \mathrm{s.} 15 \mathrm{f}$.

3 Stille 1999 s. $19 \mathrm{f}$.

4 Jfr Williams 2000 s. 85.

$5 \quad$ Stille 1999 s. 17 med tabell 1. 
av Johan Liljegren på 1800-talet. ${ }^{6}$ Stille bygger främst på Liljegren, och kallar de 16 runorna i den vikingatida runraden för fä, ur, turs, os, red, kön, hagel, nöd, is, år, sol, ti, björk, man, lag och stupman. Tre av runorna, de som brukar translittereras $\mathbf{u}, \mathbf{k}$ och $\mathbf{i}$, kan förses med en liten prick eller ett kort streck för att markera att ljudvärdet kan avvika från det som runan oftast brukar beteckna; detta kallas för stungna runor, och dessa kallar då Stille i konsekvensens namn för stunget ur, stunget kön och stunget is. ${ }^{7}$ Den generella principen bakom de så kallade runnamnen är att de inleds med det ljud som runan oftast betecknar, så att f-runan kallas fä (fvn. fé), u-runan ur (fvn. úr), p-runan turs (fvn. purs) osv. ${ }^{8}$

\section{Har runor namn?}

Stille menar således att runor har namn, något han långtifrån är ensam om. Faktum är att han ansluter sig till en både gammal och utbredd tradition, och att denna terminologi, dvs. att kalla runornas benämningar för namn, exempelvis återfinns hos den moderna runologins portalfigur i Sverige, Otto von Friesen, ${ }^{9}$ i Sven B. F. Janssons populära översikt Runinskrifter i Sverige, ${ }^{10}$ liksom i motsvarande översikter på danska och norska. ${ }^{11}$ Även i aktuella, internationella översiktsverk används motsvarande terminologi, exempelvis på tyska och engelska. ${ }^{12}$ Detta är bara ett axplock, och exemplifieringen skulle med lätthet kunna utökas högst väsentligt. Det finns dock några undantag från denna regel, för om runnamn vore namn på runor borde Nordiskt runnamnslexikon (NRL) innehålla just sådana, men så är inte fallet. I lexikonet ifråga är det i stället "egennamnen i de vikingatida nordiska runinskrifterna" som förtecknas, ${ }^{13} \mathrm{dvs}$. namn på vikingatida personer, mytiska gestalter, kristna centralgestalter och helgon samt ortnamn. Själv har jag också i ett par sammanhang vänt mig emot den traditionella termen namn och påpekat att termerna benämning eller beteckning vore mer i linje med bruket inom namnforskningen. ${ }^{14}$ Inom denna skiljer man nämligen mellan namn, i betydelsen egennamn, och appellativ, där de förra är monoreferentiella, dvs. syftar på "ett enda individuellt och specifikt objekt", medan appellativen "är gemensamma för alla ting av samma slag”. ${ }^{15}$ Utifrån en sådan definition står det klart att runornas benämningar inte kan ses som egennamn, då de inte uppfyller kravet på monoreferentialitet, utan måste betraktas som appellativ, då de är just "gemensamma för alla ting av samma slag”. Fä är således inte ett namn på en enda, specifik f-runa, utan en benämning (eller beteckning) på f-runor generellt. Strängt taget

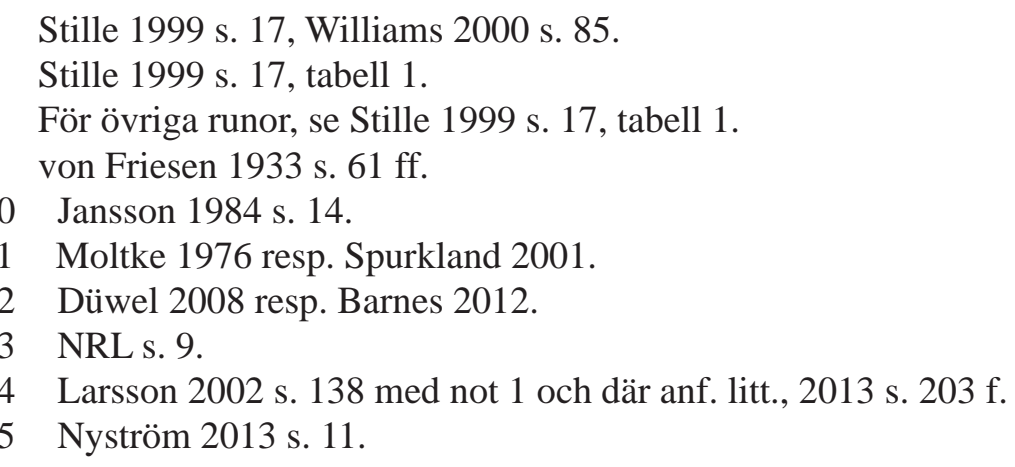


borde alltså termen namn inte användas om runor, utan den borde ersättas av benämningar (eller möjligen beteckningar).

\section{Något om runbenämningar}

Att omtala runorna med sina särskilda benämningar kan vara såväl praktiskt som tydligt; jag vänder mig alltså inte alls mot företeelsen som sådan, utan endast mot den terminologi som oftast brukas i samband med den. Därtill kommer frågan om vilka benämningar som kan vara lämpliga och hur dessa i sin tur används. Stille ger som tidigare framgått runorna benämningar på modern svenska, ${ }^{16}$ vilka uppfattas som neutrer, och då han omtalar runorna sker det i vissa fall med tillägg av exempelvis -runan/-runor ("hagelrunan", "solrunor" etc.), i vissa fall utan sådana tillägg (en a-runa blir "ett år”, fyra n-runor "fyra nöd” etc.), vilket leder till formuleringar som den följande, apropå en ovanligt utformad u-runa: ”Det är möjligt att man ska bedöma den som ett försök att rätta ett felaktigt hugget ur till ett lag." ${ }^{17}$ Den förra varianten har jag inga som helst problem med, medan jag uppfattar den senare som något otydlig och därmed mindre lyckad. ${ }^{18}$ Följer man dessutom Stilles princip att huvudsakligen utifrån de fornvästnordiska benämningarna ge motsvarigheter på modern svenska, i enlighet med hur dessa ord språkhistoriskt sett borde ha utvecklats, leder det till en del mindre lyckade homofoner, som jag ser det, inte minst då det i titeln och i avsnitt 2 nämnda ”(stunget) kön”.

\section{Avslutande ord}

Spelar det då någon roll om man kallar fä, ur, turs osv. för namn eller benämningar (alternativt beteckningar)? Vad finns det för fördelar respektive nackdelar med att förespråka att termen namn inte ska användas? En uppenbar nackdel är att det skulle gå emot en tradition som både har en gammal historia och stor utbredning i aktuell runologisk litteratur. Samtidigt måste alla discipliner kunna förändras och utvecklas över tid i takt med att nya rön och insikter uppenbarar sig. Eftersom användningen av termen namn i betydelsen egennamn inte är alltför gammal ens inom namnforskningen kan man förstås inte begära att äldre tiders runologer ska tillämpa den. Dessutom finns det en väldigt spridd användning av namn på ett sätt som egentligen strider mot den snävare definitionen inom modern namnforskning, vilket följande två titlar kan illustrera: Gökblomster, ryssgubbe och vandrande jude. Svenskt växtnamns-ABC och Orre, trast och trana. Om fåglars namn. ${ }^{19}$ Det kan också konstateras att uppfattningen att detta är namn tycks vara djupt rotad, och gärna används trots vetskap om att det kanske är oegentligt. Ingvar Svanbergs kommentar är upplysande och, tror jag, representativ för hur många resonerar:20

$16 \quad$ Stille 1999 s. 17 med tabell 1.

17 Stille 1999 s. 47.

18 Jfr Williams 2000 s. 85 not 6.

19 Svanberg 2002 resp. Nilsson 2005.

20 Svanberg 2002 s. 7. 
De svenska växtnamnen, eller snarare växtbenämningarna som en del forskare menar att det bör heta, har olika ursprung. (Eftersom växtnamn ändå är vedertaget och inte så otympligt som alternativen växtbenämning eller växtartnamn tycker jag vi kan fortsätta säga växtnamn.)

Denna typ av hänvisningar till tradition och bekvämlighet förekommer dock inte bara utanför runologins domäner, utan även inom dessa. Så här formulerar sig Michael P. Barnes om denna företeelse i en relativt nyutkommen runologisk handbok: "Unlike the letters of the roman alphabet, runes had names (or, more precisely, designations, but ”name” is the term commonly used)."21 Barnes påpekar således också att runorna egentligen inte har namn, men eftersom det är den etablerade termen är det ändå den han använder genomgående i sin bok.22

Att namn i allmänspråket har en betydelse som inte helt står i samklang med hur den moderna namnforskningen vill definiera ordet är inte mycket att säga om. Att man i verk om botanik, ornitologi och liknande ämnen också använder namn på detta sätt är inte helt lyckat, men kanske ändå fullt förståeligt, då dessa på intet sätt faller inom ramen för språkvetenskap. Runologin, däremot, har ingen sådan ursäkt, då den är en akademisk disciplin med stark språkvetenskaplig prägel. ${ }^{23}$ Som sådan borde den ta intryck av diskussioner som förs inom närliggande discipliner, till vilka namnforskningen utan tvekan bör räknas.

För att sammanfatta det ovanstående i en mening: Gärna fä, ur, turs osv., helst med något förtydligande tillägg (färunan, runan fä eller liknande), men den runforskare som slentrianmässigt fortsätter att använda termen runnamn om dessa kan visserligen sägas vara i gott sällskap, men gör ändå detta, vill jag hävda, mot bättre vetande.

\section{Litteratur och förkortningar}

Barnes, Michel P. (2012), Runes. A Handbook. Woodbridge: The Boydell Press.

- (2013), What is runology, and where does it stand today? Futhark. International Journal of Runic Studies 4, s. 7-30.

Düwel, Klaus (2008), Runenkunde. 4., überarbeitete und aktualisierte Aufl. Stuttgart-

Weimar: Verlag J.B. Metzler. (Sammlung Metzler 72.)

von Friesen, Otto (1933), De germanska, anglofrisiska och tyska runorna. I: Runorna. Utg. av Otto von Friesen. Stockholm: Albert Bonniers Förlag-Oslo: H. Aschehoug \& Co.:s Forlag-København: J. H. Schultz Forlag. (Nordisk kultur 6.) S. 1-79.

fvn. = fornvästnordiska, dvs. en gemensam benämning på fornisländska och fornnorska Jansson, Sven B. F. (1984), Runinskrifter i Sverige. 3. uppl. Stockholm: Almquist \& Wiksell Förlag AB.

Larsson, Patrik (2002), Yrrunan. Användning och ljudvärde i nordiska runinskrifter. Uppsala: Institutionen för nordiska språk. (Runrön 17.)

- (2013), Recension av Barnes 2012. Futhark. International Journal of Runic Studies 4, s. 201-207.

21 Barnes 2012 s. 21.

22 Se Larsson 2013 s. $203 \mathrm{f}$.

23 Se Barnes 2013 för en aktuell översikt över runologins utveckling och nuvarande ställning. 
Moltke, Erik (1976), Runerne i Danmark og deres oprindelse. København: Forum. Nilsson, Lennart (2005), Orre, trast och trana. Om fåglars namn. [Illustrationer: Peter Elfman] Lund: Ellerström.

NRL = Peterson, Lena (2007), Nordiskt runnamnslexikon. 5, rev. utg. Uppsala: Institutet för språk och folkminnen.

Nyström, Staffan (2013), Några generella begrepp och termer. I: Namn och namnforskning. Ett levande läromedel om ortnamn, personnamn och andra namn. Red. av Staffan Nyström (huvudredaktör), Eva Brylla, Märit Frändén, Mats Wahlberg \& Per Vikstrand. Version 1 (2013-02-19). Uppsala 2013. S. 11-16. Tillgängligt via: http:// uu.diva-portal.org/smash/record.jsf?searchId=1\&pid=diva2:606610

Runrön = Runologiska bidrag utg. av Institutionen för nordiska språk vid Uppsala universitet. $1-.1989 \mathrm{ff}$.

Spurkland, Terje (2001), I begynnelsen var fupark. Norske runer og runeinnskrifter. Oslo: Landslaget for norskundervisning (LNU)/Cappelen Akademisk Forlag. (Skrifter fra Landslaget for norskundervisning 138.)

Stille, Per (1999), Runstenar och runristare i det vikingatida Fjädrundaland. En studie i attribuering. Uppsala: Institutionen för nordiska språk. (Runrön 13.)

Svanberg, Ingvar (2002), Gökblomster, ryssgubbe och vandrande jude. Svenskt växtnamns$A B C$. Stockholm: Bokförlaget Arena. (Studia ethnobiologica 12.)

Williams, Henrik (2000), Om attribuering av runstenar i Fjädrundaland. Arkiv för nordisk filologi 115, s. 83-118. 